\title{
Cálculo del transporte de cloruros en la pasta de cemento
}

\section{Estimating the chloride transport in cement paste}

\author{
A. Princigallo ${ }^{*}$
}

Recepción/Received: 19-IV-11

Aceptación/Accepted: 22-IX-11

Publicado online/Online publishing: 31-I-12

\section{RESUMEN}

Se ha desarrollado un método para medir el coeficiente de difusión de los iones cloruro en la pasta de cemento, partiendo de una aplicación analítica de la segunda ley de Fick en un sistema de coordinadas cilíndrico. Este método, que es natural, demostró ser capaz de producir resultados de difusividad en tan solo un mes. Se consiguió reducir el tiempo de ensayo mediante el aprovechamiento de la tridimensionalidad del flujo desde el exterior al interior de la probeta. A fin de determinar la concentración de saturación, se sometieron las pastas de cemento Portland a una disolución de cloruros concentrada. Este método resultó ser útil en el estudio de los cambios del coeficiente de difusión de la pasta de cemento provocados por las reacciones de hidratación que tienen lugar en esta.

Palabras clave: difusión, propiedades de transporte, pasta de cemento, cloruros, modelación.
SUMMARY

A method was developed to measure the diffusion coefficient of chloride ions in cement paste based on an analytical solution to Fick's $2^{\text {nd }}$ law in a cylindrical coordinate system. This natural method yielded diffusivity results within as little as a month. Testing time was reduced by exploiting the three-dimensional inward flux in the specimen. In an attempt to determine the saturation concentration, dense portland cement pastes were exposed to a concentrated chloride solution. The method proved to be useful for exploring cement hydration-induced changes in the diffusion coefficient of cement paste.

Keywords: diffusion, transport properties, cement paste, chloride, modelling.

\section{INTRODUCCIÓN}

La evaluación de las propiedades de transporte en los materiales con base de cemento resulta fundamental para proyectar la vida útil de las estructuras de hormigón (1). Normalmente, el interés se centra en los umbrales

\section{INTRODUCTION}

Estimating transport properties of cement-based materials is a fundamental task vis-à-vis the service life design of concrete structures (1). The interest is generally focused on the critical thresholds of chloride

(*) CTG. Italcementi Group, Bergamo (Italia). 
críticos de concentración de cloruros que no pueden sobrepasarse en la superficie de la armadura para evitar fenómenos de corrosión. Para el cálculo de los valores límite de concentración, las propiedades de transporte y las termodinámicas son de la misma importancia. De hecho, la velocidad del proceso de transporte se representa mediante el llamado coeficiente de difusividad, mientras que la cantidad de cloruros que puede fijarse en la microestructura tras un periodo prolongado de tiempo se plasma en un determinado valor de concentración (la "concentración de saturación"). Por lo tanto, el cálculo del coeficiente de difusividad es tan importante para evaluar la probabilidad de superar un umbral de concentración concreto como el cálculo de la concentración de saturación. El objetivo del presente trabajo es el de medir el coeficiente de difusividad de los iones cloruro en la pasta de cemento y, secundariamente, de proponer un método para determinar la concentración de saturación. Es sabido que el tiempo requerido para determinar el coeficiente de difusividad se mide en meses o, incluso años, especialmente cuando se trata de materiales no porosos $(2,3)$. Se han desarrollado varios procedimientos de ensayo acelerado que se basan en la inmersión en disoluciones salinas concentradas o en la aplicación de campos eléctricos externos que, sustituyendo la difusión por fenómenos de migración, aceleran el transporte iónico en la probeta (4-10). El método que se presenta en este artículo es un método de aceleración natural, ya que se basa principalmente en la forma geométrica de la probeta (cilíndrica), que permite un rápido incremento de la penetración de iones en ella. Cuando se sumerge en una disolución salina, una probeta cilíndrica experimenta un flujo difusivo iónico desde la superficie hacia el interior (flujo tridimensional). El presente método, que es natural porque el proceso de difusión deriva de los gradientes de concentración, se basa en un modelo analítico. Dicho modelo permite calcular el coeficiente de difusividad una vez determinados tanto el valor de concentración de saturación como el promedio de la concentración medida, es decir, la concentración media de la probeta cilíndrica en su conjunto. Se ha llevado a cabo un programa experimental para validar el modelo propuesto y estudiar su utilidad en el seguimiento de los cambios microestructurales de la pasta de cemento durante su evolución físicoquímica. Se han utilizado pastas de cemento densas con tres relaciones agua/cemento similares para destacar el potencial del método para resolver distintos comportamientos en materiales solo ligeramente distintos.

\section{REFERENTES TEÓRICOS}

El presente modelo se fundamente en la existencia de un flujo másico tanto a través de la superficie lateral como a través de las bases del cilindro (Figura 1). El proceso de difusión se describe mediante la siguiente expresión [1], (11): concentration that should not be exceeded at the reinforcement surface in order to prevent corrosion phenomena. Aiming at estimating concentration values, transport and thermodynamic properties are equally important. In fact, the velocity of the transport process can be well represented by a diffusion coefficient while the amount of chloride that can be fixed into the microstructure in the long term can be represented by a certain concentration value, i.e. the "saturation concentration". Consequently, estimating the diffusion coefficient is as important as estimating the saturation concentration to evaluate the probability of exceeding a certain concentration threshold. The present work deals with the issue of measuring the diffusion coefficient of cement paste with specific reference to chloride ions transport. A method is also proposed to determine the saturation concentration. As is known, measuring the diffusion coefficient is a time-consuming procedure, especially with impervious materials $(2,3)$. Several accelerated test procedures have been set up by imposing external electrical fields, where a migration phenomenon is established replacing the diffusive one to accelerate the ionic transport into the specimen or by using concentrated salted solutions (4-10). The method presented in this paper is a natural accelerated one, the acceleration being mainly given by the selected geometry of the specimen (cylindrical) that allows a rapid increase in the concentration in the specimen. Once placed in a salted solution, the cylindrical specimen will withstand an ionic diffusive inward flow coming from the surface (three-dimensional flow). The present method is natural in that the diffusion process is derived from concentration gradients. The method is based on an analytical model that enables one to calculate the diffusion coefficient once the saturation concentration value and the measured average concentration value, i.e. the average concentration over the entire cylindrical specimen, are determined. An experimental plan has been carried out to validate the proposed model and to investigate its ability to monitor microstructural changes in the cement paste during its physical and chemical evolution. Dense cement pastes with three similar $w / c$ ratios were used to stress the potentialities of the method in resolving different performance in slightly similar materials.

\section{THEORETIC BACKGROUND}

The present model assumes a mass flow across both the side surface and the bases of a cylinder (Figure 1). The diffusion process is described by the following equation [1], (11): 


$$
\begin{aligned}
& \frac{\partial C}{\partial t}=D \cdot\left(\frac{\partial^{2} C}{\partial r^{2}}+\frac{1}{r} \cdot \frac{\partial C}{\partial r}+\frac{\partial^{2} C}{\partial z^{2}}\right) \\
& 0 \leq r \leq R \quad-L \leq z \leq L \quad t \geq 0
\end{aligned}
$$

siendo C el campo de concentración; t, $r$ y z, las coordenadas temporal, radial y axial, respectivamente; y $R$ y $L$, el radio y la mitad de la altura del cilindro. $D$ es el coeficiente de difusividad, que se mantiene constante mientras $r$, z y t no varían. Se han adoptado las siguientes condiciones límite [2]: where $C$ is the concentration field; $t, r$, and $z$ are the time, radial and axial coordinates; $R$ and $L$ are the radius and the half height of the cylinder. $D$ is the diffusion coefficient, constant with $r, z$, and $t$. The following boundary conditions were adopted [2]:

$$
\begin{array}{ccc}
C=C_{i} & 0 \leq r<R ; & -L \leq z<L ; \quad t=0 \\
C=C_{0} & r=R & t \geq 0 \\
C=C_{0} & |z|=L & t \geq 0
\end{array}
$$

Dichas condiciones representan una probeta cilíndrica con una concentración uniforme inicial $C_{i}$ y con una concentración de saturación $C_{0}$ a la que se llega en la superficie cilíndrica en el mismo momento en que entra en contacto con la disolución de cloruro y que se alcanza en la probeta en su conjunto tras un periodo de tiempo prolongado. La solución analítica al problema radial que se indica a continuación se ha descrito en (12), [3]:
Such conditions represent a cylindrical specimen with a uniform initial concentration $C_{i}$, with a saturation concentration, $C_{0}$, being reached at the cylindrical surface immediately at the time of exposure to the chloride solution and in the long term in the whole bulk of the specimen. The analytical solution to the radial problem is given by (12), [3]:

$$
C_{r}\left(r, t, C_{0}, C_{i}, D, R\right)=C_{i}+\left(C_{0}-C_{i}\right)\left[1-\frac{2}{R} \sum_{n=1}^{\infty} \frac{e^{-D \alpha_{n}^{2} t} J_{0}\left(r \alpha_{n}\right)}{\alpha_{n} J_{1}\left(R \alpha_{n}\right)}\right]
$$

siendo $a_{n}$ las raíces de la ecuación de Bessel [4]:

where $a_{n}$ are the roots of the Bessel's equation [4]:

$$
J_{0}\left(R \alpha_{n}\right)=0
$$

mientras que el desarrollo de la solución axial [5] se halla en (13):

$$
C_{z}\left(z, t, C_{0}, C_{i}, D, L\right)=C_{i}+\left(C_{0}-C_{i}\right)\left\{1-\frac{4}{\pi} \sum_{n=0}^{\infty}\left\{\frac{(-1)^{n}}{2 n+1} e^{\frac{-D(2 n+1)^{2} \pi^{2} t}{4 L^{2}}} \cos \left[\frac{(2 n+1) \pi z}{2 l}\right]\right\}\right\}
$$

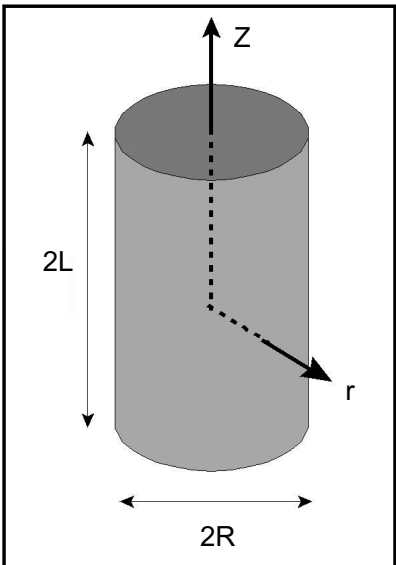

Figura 1. Forma geométrica de la probeta. Figure 1. Specimen geometry. 
En el presente modelo se ha considerado que los flujos radial y axial son independientes y se ha adoptado la siguiente función [6]:
In this model, the radial and axial flows have been assumed to be independent of one another and the following function [6]:

$$
C\left(r, z, t, C_{0}, C_{i}, D, R, L\right)=C_{i}+\left(C_{0}-C_{i}\right)\left[1-\chi\left(r, t, C_{0}, C_{i}, D, R\right) \cdot \psi\left(z, t, C_{0}, C_{i}, D, L\right)\right]
$$

como solución global, en la que [7]:

has been chosen as the overall solution where [7]:

$$
\begin{aligned}
& \chi\left(r, t, C_{0}, C_{i}, D, R\right)=1-\frac{C_{r}\left(r, t, C_{0}, C_{i}, D, R\right)-C_{i}}{C_{0}-C_{i}} \\
& \psi\left(z, t, C_{0}, C_{i}, D, L\right)=1-\frac{C_{z}\left(z, t, C_{0}, C_{i}, D, L\right)-C_{i}}{C_{0}-C_{i}}
\end{aligned}
$$

Carslaw y Jagger (14) describen un caso análogo para el transporte del flujo térmico. Por lo tanto, el modelo de concentración promedio se definió como [8]:
Carslaw and Jagger (14) describe an analogue case for the transport of heat flow. The average concentration was so modelled as [8]:

$$
\bar{C}\left(t, C_{0}, C_{i}, D, R, L\right)=\frac{\int_{0}^{2 \pi} \int_{-L 0}^{L R} C\left(r, z, t, C_{0}, C_{i}, D, R, L\right) \cdot r \partial r \partial z \partial \theta}{V}
$$

donde $V=2 \pi L R^{2}$ es el volumen de la probeta. El coeficiente de difusividad, promediado en el rango temporal 0 -t* , se ha calculado numéricamente despejando $D$ en la siguiente expresión mediante la aplicación Matlab ${ }^{\circledR}$ [9]: where $V=2 \pi L R^{2}$ is the volume of the specimen. The diffusion coefficient, averaged in the time range $0-t^{*}$, has been calculated by numerically solving for $D$ in the following equation using the Matlab ${ }^{\circledR}$ environment [9]:

$$
\bar{C}\left(t^{*}, C_{0}, C_{i}, D, R, L\right)=C^{m}\left(t^{*}\right)
$$

siendo $\mathrm{Cm}^{\mathrm{m}}\left(\mathrm{t}^{*}\right)$ el valor promedio de la concentración medida en $t^{*}$. Para la resolución numérica de las ecuaciones [9], [8] y [4] se utilizaron las funciones de la propia aplicación ("fzero", "dblquad" y "besselj" respectivamente), aunque también se tuvieron que introducir algunas modificaciones de código menores. Las sumas infinitas necesarias para las ecuaciones 3 y 5 se limitaron a un número entero finito, $\mathrm{N}=10$, al considerar que la aportación de más elementos a la suma carecía de importancia. El modelo parte también de la hipótesis que de cada campo de concentración se deduce un valor promedio de concentración único, una vez fijada la concentración de saturación. Además, en el rango temporal $0-\mathrm{t}^{*}$, se considera que los cambios que experimenta la microestructura son limitados de modo que el coeficiente de difusividad pueda resultar prácticamente constante. En consecuencia, para poder tener en cuenta los cambios del coeficiente de difusividad que corresponderían a las modificaciones habidas en la pasta de cemento, se han de definir otros rangos $0-\mathrm{t}^{*}$ diferentes. No se ha modelizado expresamente la reactividad de las distintas especies que se difunden. Por todos los motivos expuestos, el coeficiente de difusividad (tal y como se define en la ecuación 9) debe considerarse como un parámetro efectivo. El núcleo del modelo [ec. 4-7] se desarrolló para calcular el coeficiente de difusividad tras haber medido el perfil where $C^{m}\left(t^{*}\right)$ is the measured average concentration at $t^{*}$. In particular, solving [9], [8] and [4] numerically involved using built-in functions ("fzero", "dblquad" and "besselj" respectively) with minor further code implementation needed. The infinite sums required in [3] and [5] were bound to a finite integer, $N=10$, having considered negligible any further inputs to the sum. The model also assumes that each concentration field infers one specific average concentration value being the saturation concentration fixed. Moreover, in the time range $0-t^{*}$, the microstructure should be assumed to have limited changes so that the diffusion coefficient may be approximated constant. As a consequence, changes in the diffusion coefficient with time, accounting for microstructural changes in the cement paste, can be taken into account by considering different 0 -t*ranges. The reactivity of diffusive species is not explicitly modelled. For the aforementioned reasons, the diffusion coefficient, as defined by [9], shall be considered as an effective parameter. The core of the model [eq. 4-7] was developed to estimate the diffusion coefficient after measuring a profile of chloride concentration in 
de concentración de cloruros en probetas cilíndricas de hormigón que se habían sometido a un entorno marino $(15,16)$.

\section{MATERIALES Y MÉTODOS}

Se prepararon pastas con el cemento CEM I 52,5 R y relaciones agua/cemento de $0,27,0,30$ y 0,33 , que se vertieron en moldes cilíndricos con una altura de $3,5 \mathrm{~cm}$ y un radio de $1,5 \mathrm{~cm}$. Durante las primeras $24 \mathrm{~h}$ se mantuvieron los moldes en un entorno de humedad relativa cercana al $100 \%$ y a $23^{\circ} \mathrm{C}$. Después de desmoldarlas, las probetas se curaron en bolsas de plástico selladas durante seis días en agua a $60^{\circ} \mathrm{C}$. Posteriormente, se procedió a su inmersión en una disolución acuosa de $\mathrm{NaCl}$ (saturación del $90 \%$ ) a $23{ }^{\circ} \mathrm{C}$ durante hasta 420 días. A distintos tiempos de ensayo, se determinó la concentración media (es decir, la concentración total de cloruro promediada en el conjunto de la probeta cilíndrica), Cm, mediante el método químico descrito en (17). Para realizar dicho análisis, se molió la muestra hasta que, en su totalidad, pudiera pasar un tamiz de $90 \mu \mathrm{m}$. La concentración (promedio) inicial, $C_{i}$ de iones cloruro se determinó en las probetas cilíndricas antes de someterlas al ataque de cloruros. Los resultados de esta medición se recogen en la Tabla 1. La concentración de saturación, $C_{0}$, se obtuvo midiendo la concentración de cloruro de las muestras resultantes de partir las probetas cilíndricas originales en ocho fragmentos similares, a los que se sometieron al mismo tratamiento salino que las probetas enteras. Se optó por este procedimiento en la suposición de que las condiciones de saturación se alcanzarían más rápidamente en probetas de tamaño reducido. Se realizó otro ensayo en esta misma suposición consistente en moler probetas idénticas a las cilíndricas originales hasta un tamaño de grano de entre 0,5 y $1,0 \mathrm{~mm}$. Los granos resultantes se mantuvieron inmersos en la misma disolución salina durante 30 días. La concentración media se calculó a partir de los datos obtenidos de las probetas cilíndricas enteras $\left(C^{m}\right)$ y las fragmentadas $C_{m s}$. Antes de medirlas, las probetas se sumergieron en agua destilada para reducir la cantidad residual de disolución en su superficie. Se cylindrical concrete specimens exposed to a marine environment $(15,16)$.

\section{MATERIALS AND METHODS}

Pastes were prepared with CEM I $52.5 R$ at $w / C$ ratios of $0.27,0.30$ and 0.33 and used to obtain several cylindrical specimens with a height of $3.5 \mathrm{~cm}$ and a radius of $1.5 \mathrm{~cm}$. Moulded specimens were exposed for the first $24 \mathrm{~h}$ in an air water-saturated environment at $23{ }^{\circ} \mathrm{C}$. After demoulding, the specimens were sealed in a plastic bag and placed for further 6 days in water at $60{ }^{\circ} \mathrm{C}$. Afterwards specimens were exposed to $\mathrm{NaCl}$ water solution (90\% saturation) at $23{ }^{\circ} \mathrm{C}$ up to 420 days. The average concentration, i.e. the total chloride concentration averaged on a whole cylinder specimen, $\mathrm{Cm}^{m}$, was measured at different times by a chemical method described in (17). To this end, the entire sample was ground to pass a $90 \mu \mathrm{m}$ sieve. The (average) initial concentration, $C_{i}$, of chloride ions was measured using the cylindrical specimens before exposure to chloride solution (cf. Table 1). The saturation concentration, $C_{0}$, was determined by measuring the chloride concentration on 8 test pieces obtained by splitting the original cylindrical specimens and exposing each piece to the same salted solution. The reason for adopting such a procedure was the assumption that smaller specimens reach saturation conditions more quickly. A further attempt to exploit such an assumption was made by obtaining ground specimens with a grain size range between 0.5 and 1.0 $\mathrm{mm}$ from the original cylindrical specimens. Ground specimens were then exposed for 30 days to the same salted solution. Measurement of the average concentration using cylindrical specimen $\left(\mathrm{C}^{\mathrm{m}}\right)$ and split specimens, $C_{m s}$ were performed. Before each measurement, quenching in distilled water was also performed to lower the residual amount of solution on the specimens. The value of $C^{m s}$ was expected to be approaching $C_{0}$ at long ages. However, the uncertainty associated with the determination of $C_{0}$ should be

Tabla 1 / Table 1

Valores de concentración de cloruros inicial $\left(\mathrm{C}_{\mathrm{i}}\right)$ y de saturación $\left(\mathrm{C}_{0}\right)$.

Measures of $C_{i}$ and esteemes of $C_{0}$.

\begin{tabular}{|c|c|c|c|c|c|}
\hline \multirow{2}{*}{$\begin{array}{l}\text { Probeta / Specimen } \\
\text { Cilíndrica / Cylindrical }\end{array}$} & \multicolumn{2}{|c|}{$a / c / w / c$} & 0.27 & 0.30 & 0.33 \\
\hline & \multicolumn{2}{|c|}{ Concentración inicial Ci [\%] / Initial concentration Ci [\%] } & 0.09 & 0.05 & 0.04 \\
\hline \multirow{4}{*}{$\begin{array}{l}\text { Fragmentada / Size } \\
\text { reduced (split) }\end{array}$} & \multirow{5}{*}{$\begin{array}{l}\text { Valores aproximados de concentración } \\
\text { de saturación } \mathrm{C}_{0}[\%] \text { / Approximated } \\
\text { saturation concentration values } C_{0}[\%]\end{array}$} & $\mathrm{C}_{\mathrm{ms}} @ 21$ días & 1.66 & 1.96 & 2.44 \\
\hline & & $\mathrm{C}_{\mathrm{ms}} @ 50$ días & 2.08 & 2.62 & 3.15 \\
\hline & & $\mathrm{C}_{\mathrm{ms}} @ 140$ días & 2.49 & 2.96 & 3.17 \\
\hline & & $\mathrm{C}_{\mathrm{ms}} @ 420$ días & 3.01 & 3.38 & 3.71 \\
\hline $\begin{array}{c}\text { Molida (fracción } \\
0.5-1 \mathrm{~mm} \text { ) / Ground } \\
\text { (fraction } 0.5 \div 1 \mathrm{~mm} \text { ) }\end{array}$ & & $\mathrm{C}_{\mathrm{gs}} @ 30$ días & NA & 4.63 & 3.04 \\
\hline
\end{tabular}


esperaba que el valor de $C_{m s}$ se acercara a $C_{0}$ a tiempos de inmersión prolongados. No obstante, ante la incertidumbre asociada a la determinación de $\mathrm{C}_{0}$, este aspecto debe ser objeto de estudios posteriores. Para simplificar, en el presente estudio el valor medido en las muestras molidas se consideró el valor más aproximado de $\mathrm{C}_{0}$, teniendo en cuenta también el periodo relativamente breve de tiempo necesario para su determinación. Sin embargo, el uso de material molido pudo dar lugar a la aparición de otro fenómenos espurios (por ejemplo, lixiviación) cuya investigación no se ha abordado en el presente trabajo. En la Figura 2 se reproduce una imagen de las probetas enteras, fragmentadas y molidas. Como parámetro para evaluar la evolución de la microestructura de la pasta de cemento, se eligió la porosidad de las probetas, medida con un porosímetro de intrusión de mercurio Thermo Scientific Pascal 140/240. further investigated. For the sake of simplicity, the present study considers the value measured on the ground specimen as the most appropriate approximation of $C_{0}$ also on account of the relatively short time needed for its determination. Nevertheless, when using ground specimens, other spurious phenomena (e.g. leaching), not further investigated in the present paper, could in principle arise. A picture of cylindrical, split and ground specimens is given in Figure 2. In order to appraise the evolution of the microstructure of the cement paste, porosity measurements were also performed on the same specimens using a mercury intrusion porosimeter.

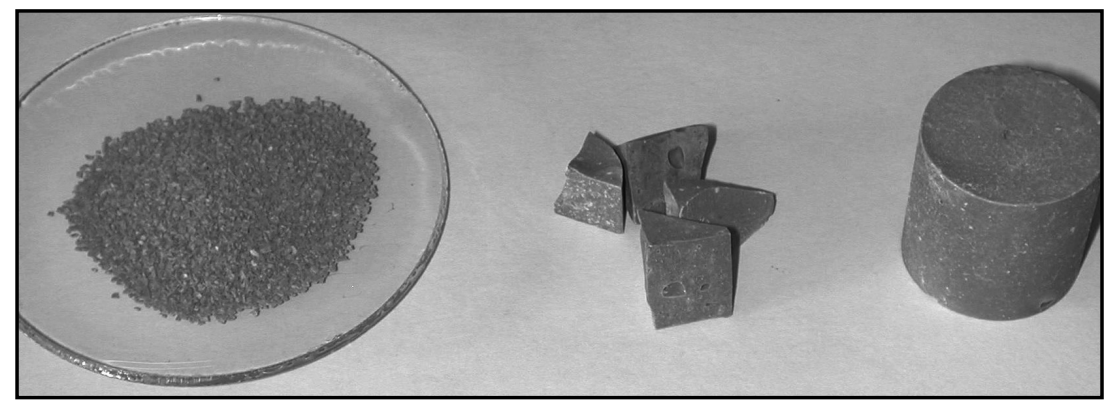

Figura 2. Probetas (cilíndricas, fragmentadas y molidas).

Figure 2. Specimens (cylindrical, split and ground).

\section{RESULTADOS EXPERIMENTALES}

En la Figura 3 se representan las concentraciones medias de $\mathrm{Cl}^{-}$en función del tiempo medidas en las pastas de cemento preparadas con las tres relaciones agua/cemento analizadas. La concentración aumentó a lo largo del tiempo y con el incremento de la relación agua/cemento, como cabía esperar. La correlación lineal de la representación logarítmica resultó de la aplicación de una ley de potencias bien ajustada a los datos experimentales. A pesar de la escasa diferencia entre las tres relaciones agua/cemento elegidas y de los bajos valores de estas, las tres curvas se distinguen bien. Sus correspondientes intervalos de confianza se indican asimismo en el gráfico. En la Tabla 1 se recogen las concentraciones medias (es decir, los valores $\mathrm{C}_{0}$ aproximados) de las probetas partidas $\mathrm{y}$ molidas tras 21, 50, 140 y 420 días de inmersión. Como puede verse en la tabla, se pueden alcanzar valores de concentración $\mathrm{C}_{\mathrm{gs}}$ similares o superiores a los detectados en los fragmentos tras 420 días $\left(C_{m s}\right)$ en un plazo de tan solo 30 días mediante la simple reducción del tamaño de las muestras a $0,5 \div 1 \mathrm{~mm}$. La Tabla 2 y la Figura 4 recogen los coeficientes de difusividad calculados por el modelo a partir de los valores $\mathrm{C}_{0}$ aproximados de la Tabla 1.

\section{EXPERIMENTAL RESULTS}

Figure 3 shows the average concentration versus time measured on the cement paste for the three $\mathrm{w} / \mathrm{c}$ ratios selected. The concentration increased with increasing time and increasing $w / c$ ratios, as intuitively expected. A power law fitted the experimental data well leading to a linear correlation in the logarithmic diagram. In spite of the small differences among the three $\mathrm{w} / \mathrm{c}$ ratios and the low $w / c$ ratio values chosen, the three curves seem to be quite distinct one from another, also considering their confidence intervals. Table 1 shows the average concentrations (i.e. approximated $C_{0}$ values) measured on split specimens after 21, 50, 140 and 420 days of exposure. Table 1 shows how concentration values, $C_{g s}$ similar to or higher than those found after 420 days on split specimens $\left(C_{m s}\right)$ can be reached within a 30 days exposure time simply by crushing the specimen down to down to the $0.5 \div 1 \mathrm{~mm}$ grain size range. The output diffusion coefficients calculated taking approximated $C_{0}$ values from Table 1 are given in Table 2 and Figure 4. The diffusion coefficients, which increased consistently with increasing $w / c$ ratios, decreased with increasing time 
Se pudo comprobar que en todos los casos, los coeficientes de difusividad: aumentaron con el incremento de la relación agua/cemento; disminuyeron con el aumento del tiempo de inmersión en la disolución de cloruro hasta los 420 días; y se redujeron a medida que mejoraba la estimación del valor de $\mathrm{C}_{0}$ (es decir, con el aumento del valor $\mathrm{C}_{0}$ utilizado en el modelo). En la Figura 4 se representan los coeficientes de difusividad calculados al tomar como valor aproximado de $\mathrm{C}_{0}$, los $\mathrm{C}_{\mathrm{ms}}$ medidos a 420 días. Debe destacarse la clara evolución descendente del coeficiente de difusividad a lo largo del tiempo, que se revela lineal $\left(R^{2}>0,95\right)$ en la escala logarítmica. El aumento del coeficiente de difusividad con el incremento de la relación agua/cemento antes mencionado se debió a la mayor porosidad en las pastas con relaciones agua/cemento más altas. La disminución del coeficiente con el tiempo ha podido relacionarse con el avance de las reacciones de hidratación que provocan un cambio en la porosidad tendente a la reducción del tamaño de los poros. Se ha planteado la posibilidad de que todas las pastas examinadas se hubieran desecado durante el periodo de acondicionamiento. Los autores observaron un fenómeno similar en of exposure in the chloride solution up to 420 days and decreased with improved $C_{0}$ approximation (i.e. with higher model input $C_{0}$ values). In Figure 4, the calculated diffusion coefficients are plotted taking $C^{m s}$ measured at 420 days as the approximated $C_{0}$ value. An apparent linear decrease $\left(R^{2}>0.95\right)$ in the diffusion coefficient with time was observed in the loglog scale. The diffusion coefficient also increased with increasing $w / c$ ratios due to the higher porosity level in pastes with higher w/c ratios; the reduction with time can be related to the proceeding of hydration reactions that cause porosity to shift towards smaller pores. It was assumed that all the examined pastes would undergo self-desiccation during the conditioning time. A similar phenomenon had already been observed by electrical methods (18). Figures 5-7 show the cumulative and differential pore size distribution of the pastes with $w / c$ ratios of $0.27,0.30$ and 0.33 respectively before the exposure to the chloride solution and after 140 and 600 days of exposure. From Figure 5 it is possible to notice, for a paste with $\mathrm{w} / \mathrm{c}$ 0.27 , a smooth increase in the pore volume over time

Tabla 2 / Table 2

Coeficientes de difusión calculados suponiendo diferentes valores aproximados de $\mathrm{C}_{0}$ ( $\operatorname{con} \mathrm{N}=10$ ). Calculated diffusion coefficients assuming different approximated $C_{0}$ values (model parameter $N=10$ ).

\begin{tabular}{|c|c|c|c|c|c|c|c|c|c|}
\hline \multirow{2}{*}{$\frac{D \times 10^{12}\left[\mathrm{~m}^{2} / \mathrm{s}\right]}{\mathrm{w} / \mathrm{c}}$} & \multicolumn{3}{|c|}{$\mathrm{C}_{\mathrm{ms}} @ 140$ días / days } & \multicolumn{3}{|c|}{$\mathrm{C}_{\mathrm{ms}} @ 50$ días / days } & \multicolumn{3}{|c|}{$\mathrm{C}_{\mathrm{ms}} @ 21$ días / days } \\
\hline & 0.27 & 0.30 & 0.33 & 0.27 & 0.30 & 0.33 & 0.27 & 0.30 & 0.33 \\
\hline 7 días / days & 3.10 & 4.60 & 7.50 & 4.67 & 6.09 & 7.62 & 8.17 & 12.10 & 14.3 \\
\hline 21 días / days & 2.26 & 3.27 & 4.30 & 3.53 & 4.45 & 4.37 & 6.46 & 9.93 & 8.72 \\
\hline 50 días / days & 2.10 & 2.77 & 4.26 & 3.46 & 3.93 & 4.34 & - & - & - \\
\hline 140 días / days & 1.82 & 2.43 & 3.36 & - & - & - & - & - & - \\
\hline
\end{tabular}

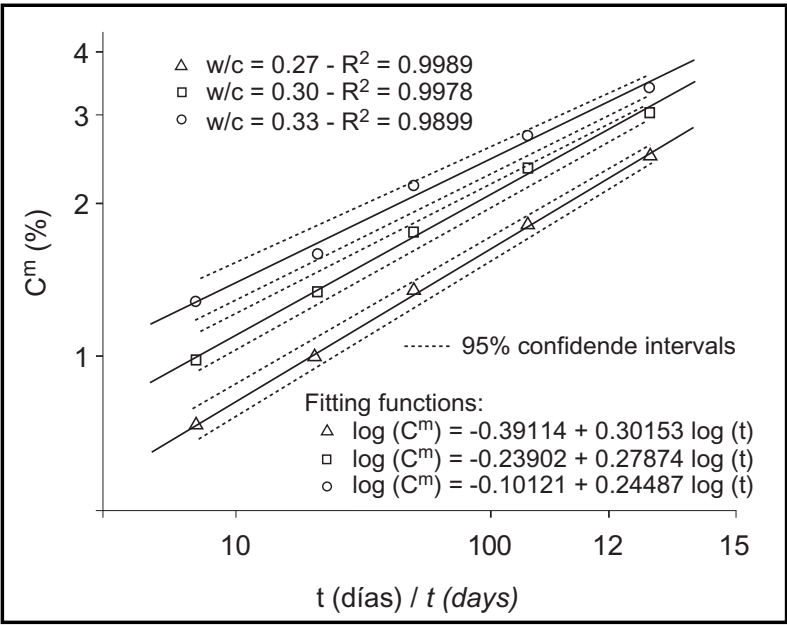

Figura 3. Concentración media de cloruro en función del tiempo (probetas cilíndricas) para relaciones agua/cemento $=0,27,0,30$,

0,33 . También se recogen las curvas de ajuste lineal y los intervalos de confianza al $95 \%$.

Figure 3. Chloride average concentration versus time (cylindrical specimens) for $w / c=0.27,0.30,0.33$. Linear fitting and regression curves at $95 \%$ confidence are also reported.

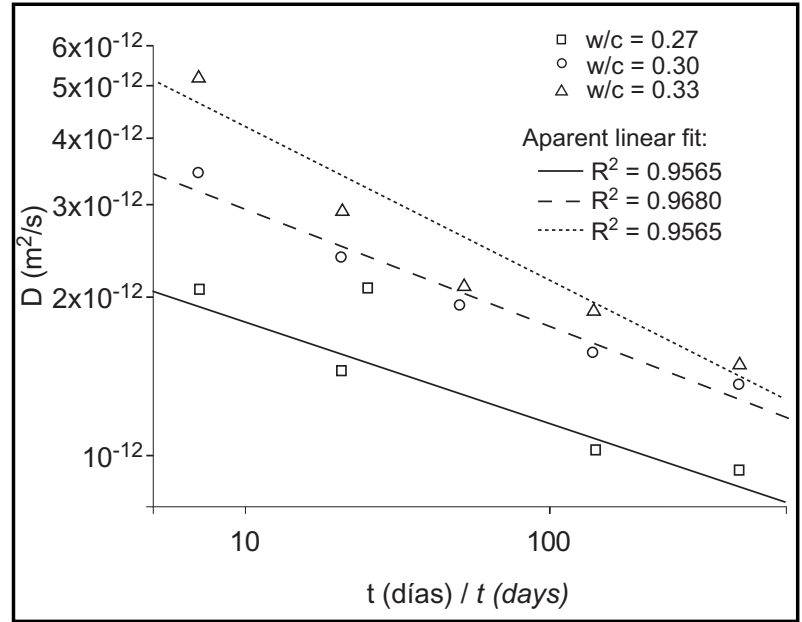

Figura 4. Coeficientes de difusividad en función del tiempo para diferentes relaciones agua/cemento tomando como valores $\mathrm{C}_{0}$ aproximados las $\mathrm{C}_{\mathrm{ms}}$ a 420 días.

Figure 4. Diffusion coefficients versus time for different $\mathrm{w} / \mathrm{c}$ ratios using $C_{m s} @ 420$ days as approximated $C_{0}$ values. 
un estudio anterior en el que se aplicaron métodos eléctricos (18). En las Figuras 5-7 se muestran la distribución del tamaño del poro relativa y acumulada de las pastas con relaciones agua/cemento de 0,27, 0,30 y 0,33 respectivamente, antes de la inmersión en la disolución de cloruro y después de 140 y 600 días de tratamiento. En la Figura 5 se puede observar que en el caso de la pasta con una relación agua/cemento de 0,27 se produce un claro incremento del volumen de los poros de menos de $10 \mathrm{~nm}$ a lo largo del tiempo. Las Figuras 6 y 7 demuestran que al incrementar la relación agua/cemento de 0,27 a 0,30 y 0,33 respectivamente, el volumen total de los poros aumenta con el tiempo en las primeras fases de hidratación. Estos resultados son acordes con el incremento

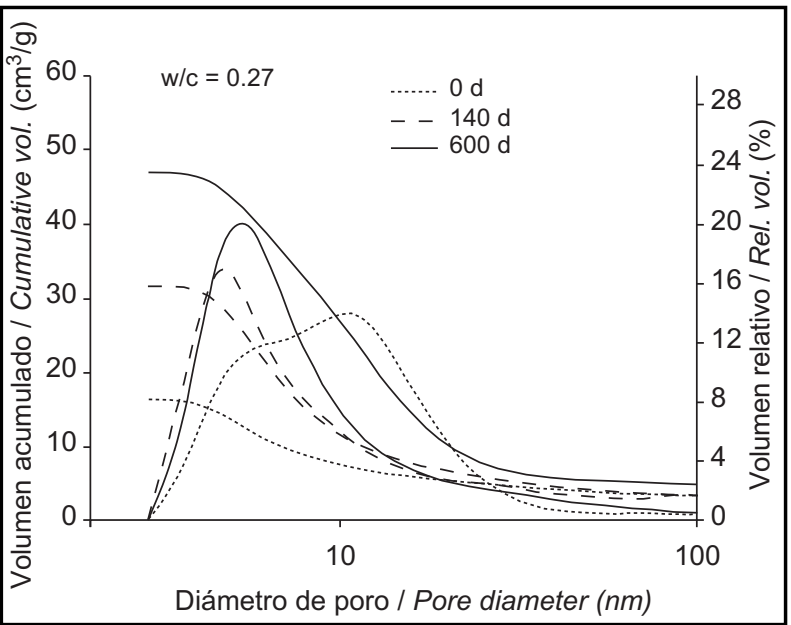

Figura 5. Distribución del tamaño de los poros a 0, 140 y 600 días en una pasta de cemento con una relación agua/cemento $=0,27$.

Figure 5. Pore size distribution at 0,140 and 600 days for a cement paste with $w / c=0.27$.

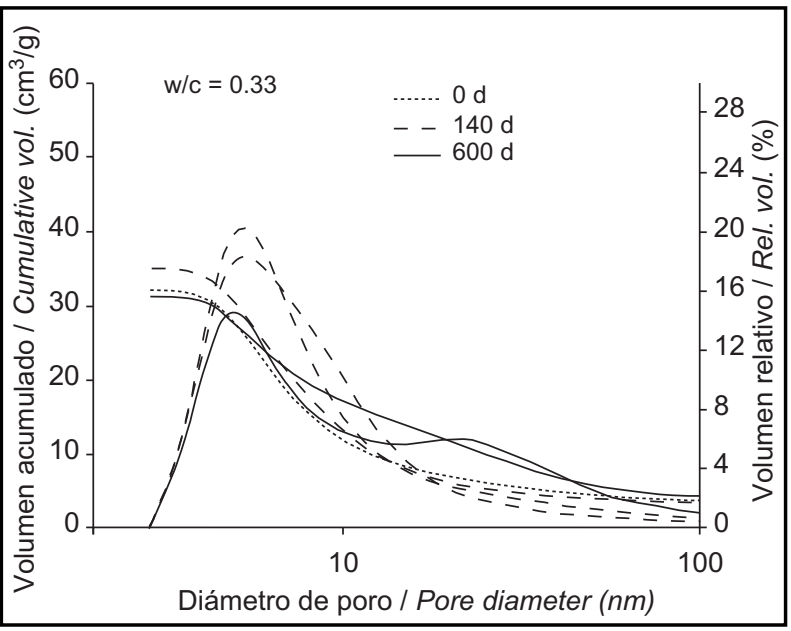

Figura 7. Distribución del tamaño de los poros a 0, 140 y 600 días en una pasta de cemento con una relación agua/cemento $=0,33$.

Figure 7. Pore size distribution at 0,140 and 600 days for a cement paste with $w / c=0.33$. for pores smaller than $10 \mathrm{~nm}$. Figures 6 and 7 evidence how, by increasing the $w / c$ ratio from 0.27 to 0.30 and to 0.33 respectively, the total pore volume increased with time at early hydration ages. These results confirm the observed increase in the diffusion coefficient at increasing $w / c$ ratios and its reduction with time. At longer times a shift of the pore volume toward larger pores seems to occur in pastes with higher $w / c$ ratios. These results also support the idea that the measured diffusion coefficient, according to the present method, could be used to monitor microstructural changes in the cement paste. In order to visually check the consistency of the model, the estimated concentration field in the cylindrical

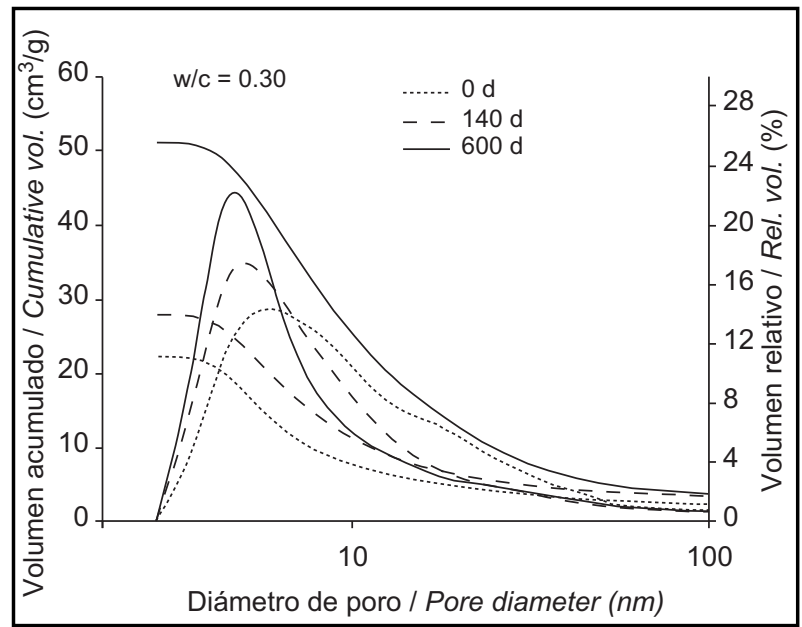

Figura 6. Distribución del tamaño de los poros a 0, 140 y 600 días en una pasta de cemento con una relación agua/cemento $=0,30$.

Figure 6. Pore size distribution at 0,140 and 600 days for a cement paste with $w / c=0.30$.

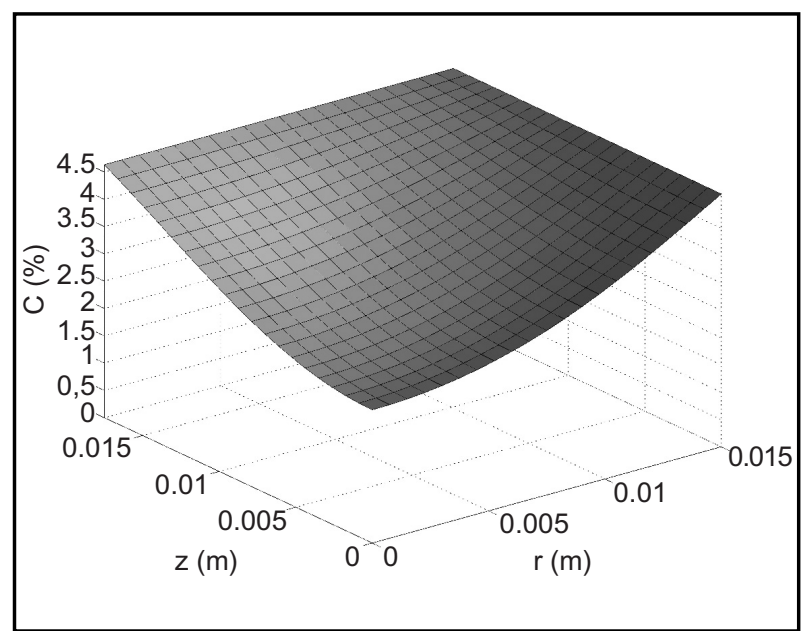

Figura 8. Patrón de concentración calculado para una relación agua/cemento $=0,30, \mathrm{C}_{0} 4,63 \%, \mathrm{D} 1,16 \cdot 10^{-12} \mathrm{~m}^{2} / \mathrm{s}$, t 420 días - $(\mathrm{N}=10)$.

Figure 8. Estimated concentration pattern for $w / c 0.30$, $C_{0} 4.63 \%, D 1.16 \cdot 10^{-12} \mathrm{~m}^{2} / \mathrm{s}$, t 420 days $-(\mathrm{N}=10)$. 
observado del coeficiente de difusividad a medida que aumenta la relación agua/cemento y con su reducción con el tiempo. A tiempos más prolongados, parece que se produce un cambio en el volumen del poro hacia poros más grandes en las pastas con las relaciones agua/cemento mayores. Los resultados obtenidos apoyan la idea de que el coeficiente de difusión medido siguiendo el presente método podría utilizarse para hacer un seguimiento de los cambios microestructurales en la pasta de cemento. Para comprobar visualmente la coherencia del modelo, en la Figura 8 se recoge el campo de concentración calculado a los 420 días de inmersión de la probeta cilíndrica con una relación agua/cemento de 0,30.

\section{COMPARACIÓN CON LOS RESULTADOS DE OTROS ESTUDIOS}

Debido a las dudas sobre su precisión, en estos momentos no existe ningún método de ensayo de referencia reconocido a escala europea para determinar las propiedades de transporte de iones en las pastas de cementos. Sin embargo, aquí se relacionan algunas referencias para contextualizar el marco en el que deben considerarse los resultados derivados del presente trabajo: tras 60 días de tratamiento, Tennis et al. (19) obtuvieron un coeficiente de difusividad de $2,3 \cdot 10^{12} \mathrm{~m}^{2} / \mathrm{s}$ para una pasta con una relación agua/cemento de 0,35; Bentz et al. (20) calcularon para una pasta con una relación agua/cemento de 0,3 sometido a tratamiento durante 130 días, un coeficiente de difusividad de $1,4 \cdot 10^{12} \mathrm{~m}^{2} / \mathrm{s}$; en un ensayo de 140 días, Halamickova et al. (21) hallaron un coeficiente de difusividad de $1 \cdot 10^{11} \mathrm{~m}^{2} / \mathrm{s}$ para una pasta con una relación agua/cemento de 0,4 ; Jensen et al. (22) describieron una prueba de 30 días a $35^{\circ} \mathrm{C}$ en que el coeficiente de difusividad para una pasta con una relación agua/cemento de 0,3 resultó ser de $1,5 \cdot 10^{12} \mathrm{~m}^{2} / \mathrm{s}$; Dridi (23) obtuvo para una relación agua/cemento de 0,3 un coeficiente de difusividad de entre $1,0 \mathrm{y}$ $1,1 \cdot 10^{12} \mathrm{~m}^{2} / \mathrm{s}$; para una relación agua/cemento cercana a 0,27 , un coeficiente de difusividad de entre 1,6 y $1,7 \cdot 10^{13} \mathrm{~m}^{2} / \mathrm{s}$; y para una relación agua/cemento de 0,35 , un coeficiente de difusividad de entre 3,0 y $4,0 \cdot 1012 \mathrm{~m} 2 / \mathrm{s}$ (interpolaciones gráficas). Aunque estos valores no se han obtenido en condiciones experimentales totalmente equiparables entre sí, parecen aproximarse a los resultados obtenidos en el presente trabajo.

\section{CONCLUSIONES}

Se ha desarrollado un método para medir el coeficiente de difusividad de iones cloruro en pastas de cemento basado en la solución analítica de la segunda ley de Fick en coordenadas cilíndricas. Presupone que existe una correlación entre la concentración media de una probeta specimen at 420 days of exposure for $w / c 0.30$ is given in Figure 8.

\section{COMPARISON WITH LITERATURE RESULTS}

At present, no test method has been recognized at European level as a reference method to determine the transport properties of cement pastes because of accuracy. Nevertheless, some references are reported here to show the context wherein the results produced in the present paper should be considered. Tennis et al. (19) reported a diffusion coefficient of $2.310^{-12} \mathrm{~m}^{2} / \mathrm{s}$ after 60 days for a paste with w/c 0.35; Bentz et al. (20) reported a diffusion coefficient of $1.410^{-12} \mathrm{~m}^{2} / \mathrm{s}$ after 130 days for a paste with w/c 0.3; Halamickova et al. (21) reported a diffusion coefficient of $1 \cdot 10^{-11} \mathrm{~m}^{2} / \mathrm{s}$ after 140 hours for a paste with $w / c$ 0.4; Jensen et. al. (22) reported a diffusion coefficient of $1.5 \cdot 10^{-12} \mathrm{~m}^{2}$ after 30 days at $35{ }^{\circ} \mathrm{C}$ for a paste with $w / c$ 0.3. Dridi (23) reported for a $w / c 0.3$ a diffusion coefficient in the range 1.0 to $1.1 \cdot 10^{-12} \mathrm{~m}^{2} / \mathrm{s}$; the diffusion coefficient was found to be in the range 1.6 to $1.7 \cdot 10^{-13} \mathrm{~m}^{2} / \mathrm{s}$ for a $\mathrm{w} / \mathrm{c}$ close to 0.27 and in the range 3.0 to $4.0 \cdot 10^{-12} \mathrm{~m}^{2} / \mathrm{s}$ for $\mathrm{w} / \mathrm{c} 0.35$ (graphical interpolations). Although experimental conditions were not fully consistent, the above values seem close to the results reported in the present paper.

\section{CONCLUSIONS}

A method was developed to measure diffusion coefficient of cement pastes, based on the analytical solution of Fick's $2^{\text {nd }}$ law in cylindrical coordinates. It assumes that a correlation exists between the average concentration of the specimen and the diffusion coefficient once the 
y el coeficiente de difusividad una vez fijada la concentración de saturación. Para ello, se han medido, después de determinados tiempos de ensayo, la concentración de saturación y la concentración media de varias probetas cilíndricas. El método es más rápido que otros medios unidireccionales naturales para medir la difusión del cloruro en hormigón (24) porque aprovecha el flujo tridimensional hacia el interior de la probeta. Tras haberse constatado que la medición de la concentración de saturación es la parte del método que más se dilata en el tiempo, se ha hecho un intento de acortar la duración de este procedimiento. Con el método desarrollado, se pueden obtener parámetros útiles para describir la penetración natural de iones en una pasta de cemento densa en tan solo un mes. Para validar este modelo, se ha medido el coeficiente de difusividad en función del tiempo para tres pastas de cemento con relaciones agua/cemento bajas y similares entre sí y se ha comparado los resultados con los citados en la literatura. El coeficiente de difusividad y la concentración de saturación deben considerarse relevantes para clasificar materiales con base de cemento según sus propiedades frente al transporte de cloruros, especialmente porque es importante que no se superen los umbrales de concentración crítica. saturation concentration is set. For this purpose, the saturation concentration and the average concentration of cylindrical specimens after a certain time were measured. The method is accelerated if compared to other natural unidirectional methods for chloride diffusion in concrete (24) because it exploits a threedimensional flow moving towards the inside the specimen. Having also realized that the time needed to measure saturation concentration is the most timeconsuming part of the method, an attempt was made to accelerate this procedure. According to the method reported herein, relevant parameters describing the natural ion ingress into dense cement paste could be obtained as quickly as in one month time. To validate the model, the diffusion coefficient of three cement pastes with similar low $\mathrm{w} / \mathrm{c}$ ratios was measured as function of time and a comparison with literature sources was made. Diffusion coefficient and saturation concentration should be considered both relevant in order to rank materials for their chloride transport properties in cement-based materials.

\section{BIBLIOGRAFÍA / BIBLIOGRAPHY}

(1) FIB (CEB-FIP), "Model Code for service life design", bulletin 34, http://fib.epfl.ch/publications/fib/

(2) Page, C. L.; Short, N. L.; Tarras, A.: "Diffusion of chloride ions in hardened cement pastes", Cem. Concr. Res. 11 (3) (1981), pp. 195-406. http://dx.doi.org/10.1016/0008-8846(81)90111-3

(3) Francy, O.; François, R.: "Measuring chloride diffusion coefficients from non steady state diffusion tests", Cem. Concr. Res., 28 (7) (1998) pp. 947-953. http://dx.doi.org/10.1016/S0008-8846(98)00070-2

(4) NT BUILD 443, "Concrete, Hardened: Accelerated Chloride Penetration".

(5) Whiting, D.: "Rapid determination of the chloride permeability of concrete", Federal Highway Administration, Report na FHWA/RD81/119 (1981).

(6) ASTM C 1202-97, "Standard Test Method for Electrical Indication of Concrete's Ability to Resist Chloride Ion Penetration".

(7) Truc, O.; Ollivier, J. P.; Carcasses, M.: "A new way for determining the chloride diffusion coefficient in concrete from steady statemigration test", Cem. Conc. Res. 30 (2) (2000), pp. 217-226. http://dx.doi.org/10.1016/S0008-8846(99)00232-X

(8) NT BUILD 492, "Concrete, Mortar and Cement Based Repair Materials: Chloride Migration Coefficient from Non-steady State Migration Experiments".

(9) Castellote, M.; Andrade, C.; Alonso, C.: "Non-steady-state chloride diffusion coefficients obtained from migration and natural diffusion tests: Part II: Different experimental conditions. Joint relations", Mat. and Struc., 34 (2001), pp. 323-331. http://dx.doi.org/10.1007/BF02486483

(10) Castellote, M.; Andrade, C.; Alonso, C.: "Measurement of the steady state and non-steady state chloride diffusion coefficients in a migration teas by means of monitoring the conductivity in the anolyte chamber. Comparison with natural diffusion tests", Cem. Concr. Res, 31 (10) (2001), pp. 1411-1420. http://dx.doi.org/10.1016/S0008-8846(01)00562-2

(11) Bird, R. B.; Stewart, W. E.; Lightfoot, E.: "Fenomeni di trasporto", Ed. Ambrosiana, Milano (2004), pp. 572-671.

(12) Crank, J.: "The Mathematics of Diffusion", Oxford Science Publications (1975), pp. 47-73.

(13) Castellote, M.; Andrade, C.; Alonso, C.: "Electrochemical removal of chlorides, Modelling of the extraction, resulting profiles and determination of the efficient time of treatment", Cem. Concr. Res. 30 (4) pp. 615-621 (2000). http://dx.doi.org/10.1016/S00088846(00)00220-9

(14) Carslaw, H. S.; Jaeger, J. C.: "Conduction of Heats in Solids", Oxford Science Publications (1959), pp. 33-225. 
(15) Princigallo, A.; Cucitore, R.; Levita, G.: "Chloride Penetration in High Performance Concrete in a Marine Environment: An Experimental Verification", Cem. and Concrr. Sci. Conf., Coventry (2004).

(16) http://fasae.ibpmw.uni-essen.de/euproject/inhalt.htm

(17) UNI 9944:1992, "Corrosion and protection of reinforcing steel in concrete. Determination of the carbonation depth and of the chlorides penetration profile in concrete".

(18) Princigallo, A.; Levita, G.; Marchetti, A.; Gallone, G.; Guerrini, G. L.: "Advancements in modelling the development of microstructure in cement pastes", 7th European Conference on Advanced Materials and Processes, Rimini (2001).

(19) Tennis, P. D.; Krizek, R. J.; Jennings, H. M.: "Counter-Diffusion as indicator of durability", Proc. of the 11th Int. Congr. on the Chem. of Cem., Durban (2003).

(20) Bentz, D. P.; Jensen, O. M.; Coats, A. M.; Glasser, F. P.: "Influence of silica fume on diffusivity in cement-based materials - I. Experimental and computer modeling studies on cement pastes", Cem. Concr. Res., 6 (30) (2000), pp. 953-962. http://dx.doi.org/10.1016/S0008-8846(00)00264-7

(21) Halamickova, P.; Detwiler, R. J.; Bentz, D. P.; E. Garboczi, J.: "Water permeability and chloride ion diffusion in portland cement mortars: relationship to sand content and critical pore diameter", Cem. Concr. Res. 4 (25), (1995), pp. $790-802$. http://dx.doi.org/10.1016/0008-8846(95)00069-O

(22) Jensen, O. M.; Hansen, P. F.; Coats, A. M.; Glasser, F. P.: "Chloride ingress in cement paste and mortar", Cem. Concr. Res. 29 (9) pp. 1497-1504 (1999). http://dx.doi.org/10.1016/S0008-8846(99)00131-3

(23) Dridi, W.: "International RILEM Symposium on Concrete Modelling-CONMOD '08, RILEM Publications S.A.R.L. (2008), pp. $235-237$. (24) CEN/TS 12390-11:2010, "Testing hardened concrete - Part 11: Determination of the chloride resistance of concrete, unidirectional diffusion". 